\title{
Pathophysiology of Growth Hormone Secretion Disorders and Their Impact on Bone Microstructure as Measured by Trabecular Bone Score
}

\author{
M. KUŽMA ${ }^{1}$, Z. KILLINGER ${ }^{1}$, P. JACKULIAK ${ }^{1}$, P. VAŇUGA $^{2}$, D. HANS ${ }^{3}$, N. BINKLEY ${ }^{4}$, \\ J. PAYER ${ }^{1}$
}

${ }^{1} 5$ th Department of Internal Medicine, Faculty of Medicine, Comenius University Bratislava, University Hospital Bratislava, Bratislava, Slovak Republic, ${ }^{2}$ National Institute of Endocrinology and Diabetology, Lubochna, Slovakia, ${ }^{3}$ Center of Bone Diseases, Bone and Joint Department, Lausanne University Hospital, Lausanne, Switzerland, ${ }^{4}$ Department of Medicine, University of Wisconsin, Madison, Wisconsin, United States of America

Received June 4, 2019

Accepted October 1, 2019

\section{Summary}

This article is focused on endocrine-mediated osteoporosis caused by growth hormone (GH) disorders; adult GH deficiency and acromegaly. GH and insulin like growth factor-1 (IGF-1) stimulate linear bone growth through complex hormonal interactions and activates epiphyseal prechondrocytes. $\mathrm{GH}$, via receptor activator of nuclear factor-kappaB (RANK), its ligand (RANK-L), and the osteoprotegerin system, stimulates production of osteoprotegerin and its accumulation in bone matrix. Malfunction of this mechanism, could lead to specific bone impairment. However, the primary problem of bone disease in $\mathrm{GH}$ secretion disorders is the primary prevention of osteoporotic fractures, so it is important to determine bone quality that better reflects the patient's actual predisposition to fracture. A method estimating bone quality from lumbar spine dual $X$-ray absorptiometry (DXA) scans is trabecular bone score (TBS). TBS in addition to bone mineral density (BMD) is a promising predictor of the osteoporotic fracture risk in women with postmenopausal osteopenia. In acromegaly TBS better defines risk of fracture because BMD is normal or even increased. TBS helps to monitor the effect of growth hormone therapy. Despite these findings, TBS should not be used alone, but a comprehensive consideration of all fracture risk factors, BMD and bone turnover markers is necessary.

\section{Key words}

Growth hormone - Insulin like growth factor-1 - Bone - Bone microstructure $\bullet$ Trabecular bone score

\section{Corresponding author}

M. Kužma, 5th Department of Internal Medicine, Faculty of Medicine, Comenius University, Ružinovská 6, 82606 Bratislava, Slovac Republic. E-mail: martin.kuzma@fmed.uniba.sk

\section{Secondary endocrine-mediated osteoporosis}

Osteoporosis is characterized by low bone mass and microarchitectural deterioration of the skeleton leading to bone fragility and a predisposition to fractures. Secondary osteoporosis is defined as low bone mass with microarchitectural alterations in bone leading to fragility fractures in the presence of an underlying disease or medication. Among osteoporosis population, 30\% of females and up to $80 \%$ of males have secondary cause of osteoporosis contributing to osteoporosis. It is important to exclude secondary osteoporosis in all patients, because the management of the disease may differ (Mirza and Canalis 2015). The most common endocrine diseases associated with osteoporosis are: glucocorticoid-induced osteoporosis, hyperthyroidism, hypogonadism, hyperparathyroidism, diabetes mellitus, growth hormone deficiency and acromegaly. In this review, last two 
conditions and their impact on bone, especially bone microarchitecture, are presented.

\section{Trabecular bone score}

Trabecular bone score (TBS) is non-invasive method designed to obtain insight into trabecular microarchitecture based upon pixel gray-level variations in the dual X-ray absorptiometry (DXA) images of lumbar spine. While TBS is indirect measurement, it correlates with micro-computed tomography $(\mu \mathrm{CT})$ measures in ex vivo studies. In humans, TBS is associated with trabecular microarchitecture and bone strength by high resolution peripheral quantitative computed tomography (HRpQCT). TBS is the methodology applied to DXA images that quantify local variations in grey level and differentiate between 3-dimensional (3D) microarchitectures that exhibit the same BMD but different trabecular characteristics. TBS is not a direct physical measurement of trabecular microarchitecture, but rather an overall descriptor of bone quality. A low TBS value is associated with fewer, less well-connected and more widely distributed trabeculae, while high TBS values are correlated with better trabecular structure. To summarize, it is well documented that low TBS is associated with a higher risk of fracture independent of BMD (Hans et al. 2011, Boutroy et al. 2013, Briot et al. 2013, McCloskey et al. 2016).

\section{Adult growth hormone deficiency}

Growth hormone (GH) has pleiotropic effects. In GH deficiency, replacement therapy reduces cardiovascular morbidity and mortality, improves lipid profiles, changes body composition, and increases quality of life (Rosen et al. 1994, Arwert et al. 2005, Touskova et al. 2016). GH acts on target tissues directly, or via insulin-like growth factor 1 (IGF-1), which is produced mostly by hepatocytes. GH treatment of adults with GH deficiency (GHD) increases bone mineral density (BMD) and likely reduces fragility fracture risk (Rota et al. 2008, Conway et al. 2009, Elbornsson et al. 2012b, AppelmanDijkstra et al. 2014, Krantz et al. 2015, Mo et al. 2015). However, a clear understanding of GHD- induced osteopenia, the effects of this deficiency on bone quality/architecture, and how GH treatment may affect BMD and bone architecture (Barake et al. 2014) is lacking. GH stimulates linear bone growth through complex hormonal interactions and activates epiphyseal prechondrocytes. GH, via receptor activator of nuclear factor-kappaB (RANK), its ligand (RANK-L), and the osteoprotegerin system, stimulates production of osteoprotegerin and its accumulation in bone matrix. IGF-1 and GH affect the regulation of bone remodeling across the lifespan. The anabolic effects of GH are important to attain peak bone mass, and to achieve appropriate trabecular bone micro-architecture during late adolescence and early adulthood which affects fracture risk later in life. Prior studies demonstrate a positive effect of GH replacement on BMD, bone turnover markers, and fracture risk (Amato et al. 1993, Degerblad et al. 1995, Biermasz et al. 2001, Clanget et al. 2001, Davidson et al. 2004, Arwert et al. 2005, Rota et al. 2008, Conway et al. 2009, Jorgensen et al. 2011, Elbornsson et al. 2012a, Elbornsson et al. 2012b). In our previous multi-centric prospective study (Kuzma et al. 2014) in 147 adults (mean age 35 yrs) with GHD during 24 month of recombinant human $\mathrm{GH}(\mathrm{rhGH})$ replacement treatment an effect of rhGH on bone turnover markers, BMD and TBS was assessed. After baseline visit, during the whole treatment, the IGF-1 levels were within the reference range.

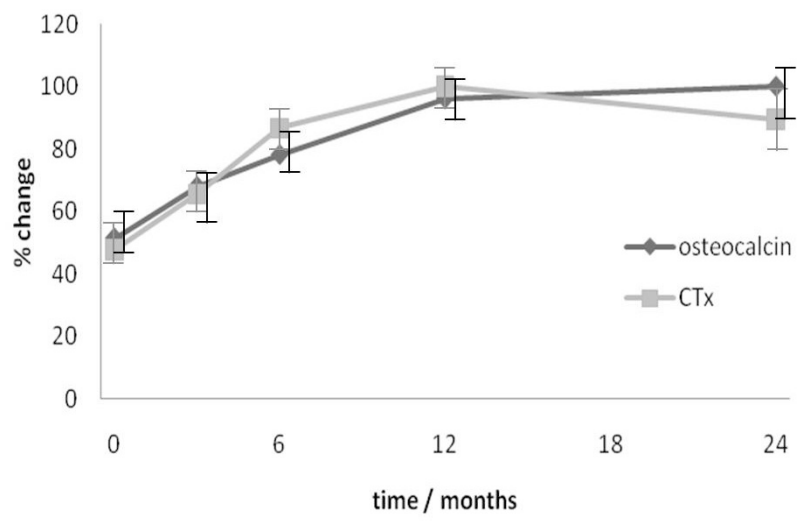

Fig. 1. Bone turnover markers during 24 month rhGH treatment.

The bone markers increased significantly after 2 years of treatment (OC levels $(\mathrm{N}=98)$ of $95.8 \%$; $\mathrm{p}<0.001$, CTx $(\mathrm{N}=95)$ levels of $82.3 \% ; \mathrm{p}<0,0001)$. During the first year of treatment, both bone markers were increasing. After the first year of rhGH treatment CTx was decreasing in contrast to OC. (Fig. 1). No significant difference in bone turnover markers was observed between genders and onset of GHD. A significant increase in the BMD lumbar spine (L-spine) was observed at month 24 of the treatment $\left(0.88 \mathrm{~g} / \mathrm{cm}^{2}\right.$ vs. $1.02 \mathrm{~g} / \mathrm{cm}^{2}$, increase of $14 \%, \mathrm{p}<0.0001$ ) (Fig. 2). This 

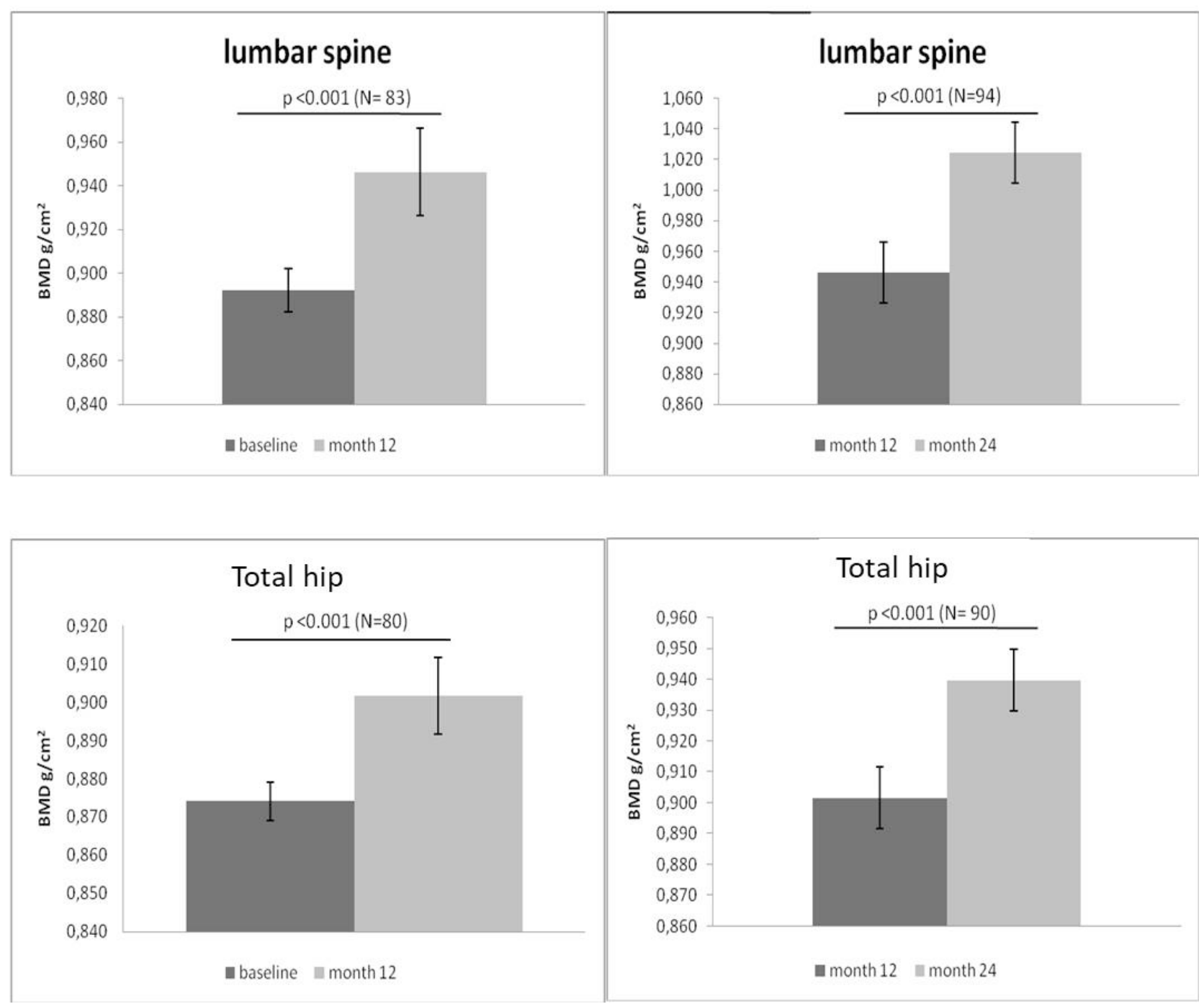

Fig. 2. BMD increase during 24 months of rhGH treatment

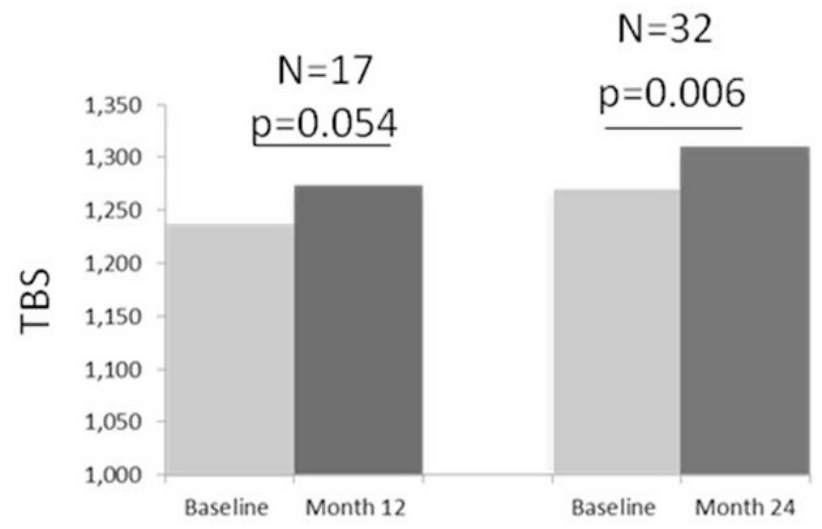

Fig. 3. Increase in TBS in the subset of GHD patients during 24-months of treatment.

increase was significantly higher in male patients compared to females $(+15 \%$ in males vs. $10 \%$ in females, $p=0.037$ ). In male patients, an initial decrease of BMD was noted. Total hip (TH) BMD after 2 years has increased of $6.7 \%\left(0.86 \mathrm{~g} / \mathrm{cm}^{2}\right.$ at vs. $\left.0.93, \mathrm{p}=0.05\right)$ (Fig. 1). BMD scans of lumbar spine were analysed in a subgroup $(\mathrm{N}=32,19$ males, 15 AO-GHD $)$ of patients to obtain TBS. An increase of $4 \%(p=0.02)$ after two years of treatment with rhGH was observed (Fig. 3).

Conclusively, a positive effect of rhGH on bone mass based on the increase of BMD and bone turnover markers was observed. Additionally, TBS increased after 2 years of treatment concordant with positive effect on bone microarchitecture.

There is a potential relationship of vitamin D deficiency with GHD. It is known that IGF-1 stimulates renal $1 \alpha$-hydroxylase and may affect bone metabolism by this mechanism (Joseph et al. 2008). This fact is supported by analysis of children with rickets, in which serum IGF-1 significantly increased after vitamin D treatment (Soliman et al. 2008, Bereket et al. 2010). Associations between 25(OH)D and IGF-1 levels have 
been found in healthy subjects (Gomez et al. 2004, Bogazzi et al. 2011) and patients with active acromegaly (Halupczok-Zyla et al. 2015). In one retrospective analysis (Ameri et al. 2013) was found that GHD subjects with $25(\mathrm{OH}) \mathrm{D}$ levels below $15 \mathrm{ng} / \mathrm{ml}$ have significantly lower IGF-1 levels than those whose $25(\mathrm{OH}) \mathrm{D}$ was above $15 \mathrm{ng} / \mathrm{ml}$. therefore, it is likely that vitamin D affects the bone response to rhGH replacement. Our next study (Kuzma et al. 2016) of 57 AO-GHD patients (29 males/28 females, mean age 34.4 years) treated with rhGH during 24 month showed potential beneficial effects of sufficient 25(OH)D3 levels on bone microarchitecture, as measured by TBS. All patients received $\mathrm{rhGH}$ in standard IGF-1-normalizing rhGH replacement regimen and were divided according $25(\mathrm{OH}) \mathrm{D}$ levels in two groups with cutoff defined as the $50^{\text {th }}$ percentile at each time point of follow up. $25(\mathrm{OH}) \mathrm{D} 3$ were measured at baseline and at months 12 and 24 of treatment. Serum 25(OH)D3 was assessed by chromatographic determination on a simple isocratic HPLC system with UV detection. To prevent overt vitamin D deficiency and adverse effect of secondary hyperparathyroidism, patients with vitamin $\mathrm{D}$ inadequacy at baseline, defined as a circulating $25(\mathrm{OH}) \mathrm{D}$ level $<50 \mathrm{nmol} / \mathrm{l}$, received cholecalciferol $800 \mathrm{IU}$ and calcium $1000 \mathrm{mg}$ daily as recommended by International Osteoporosis Foundation (IOF).

In the entire study population after 24 months of GH replacement, LS BMD increased by $7.6 \%$ and TH BMD increased by $4.5 \%$ (both $\mathrm{p}<0.05$ ), no significant effect on TBS in the entire study cohort was observed. There was no difference between TH and LS BMD change after 24 months according to $25(\mathrm{OH}) \mathrm{D}$ percentile analysis. However, a significant difference of TBS change from baseline based on vitamin D status was observed. Subjects above $50^{\text {th }}$ percentile of $25(\mathrm{OH}) \mathrm{D}$ had TBS increase of $+1.39 \pm 3.6 \%$ (mean TBS $1.37 \pm 0.13$ ) in comparison to TBS decrease of $-1.36 \pm 5.6 \%$ (mean TBS $1.29 \pm 0.15)$ in subjects whose $25(\mathrm{OH}) \mathrm{D}$ was below the $50^{\text {th }}$ percentile $(\mathrm{p}<0.05)$ (Fig. 4). A limitation of this study is that a so-called "treat to target" strategy for vitamin D supplementation was not utilized. It is likely that despite provision of a commonly recommended daily cholecalciferol dose, many of our vitamin D insufficient participants likely did not achieve an optimal $25(\mathrm{OH}) \mathrm{D}$ status. It is possible that the low $25(\mathrm{OH}) \mathrm{D}$ group remained vitamin D deficient despite supplementation thus leading to a decline in TBS despite daily supplementation. Future studies evaluating the relationship of GH treatment with vitamin D status should assure that vitamin D supplement doses do achieve optimal 25(OH)D levels.

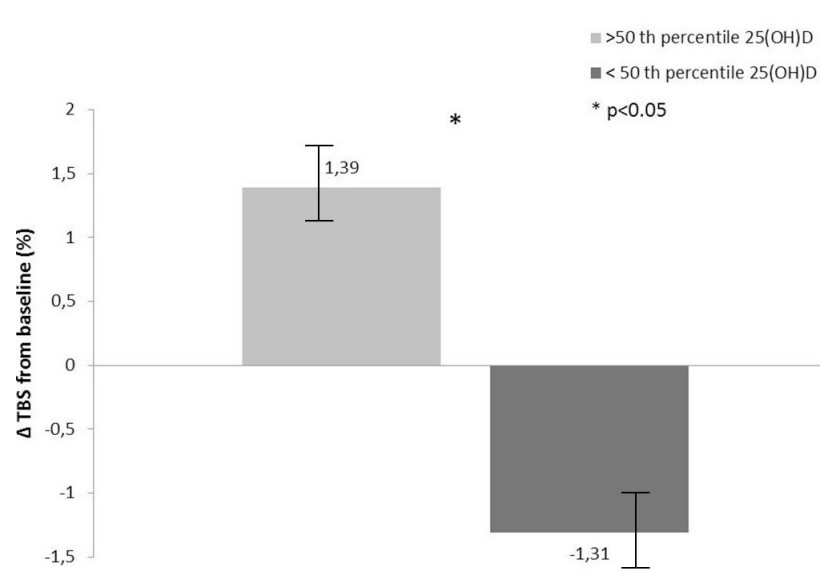

Fig. 4. Change in TBS according to vitamin $D$ levels in patients with treated with rhGH. Patients with 25OHD levels above $50^{\text {th }}$ percentil had significant increase in TBS in comparison to decrease of TBS in those vitamin D levels under $50^{\text {th }}$ percentil.

This study is showing positive effect of GH treatment on BMD with no effect of vitamin D status. However, a differential effect of GH on TBS was observed with a TBS increase only in the cohort with $25(\mathrm{OH}) \mathrm{D}$ above the 50th percentile. As such, it is possible that an optimal effect of GH treatment to improve bone quality, represented by TBS, in GHD adults is achieved only in those with sufficient $25(\mathrm{OH}) \mathrm{D}$ levels. Further studies are needed to solve this issue.

\section{Acromegaly}

Opposite to GHD, it is not surprising that some authors suggested positive effects of GH hypersecretion on bone (Riggs et al. 1972, Kayath and Vieira 1997, Vestergaard and Mosekilde 2004). However, several studies find increased prevalence of asymptomatic vertebral fractures in patients with acromegaly, regardless of bone mineral density (BMD) or disease activity (Bonadonna et al. 2005, Claessen et al. 2013, Mazziotti et al. 2013). Patients with acromegaly have elevated bone turnover markers (Stepan et al. 1979, Scillitani et al. 1997, Ueland et al. 2001) but BMD as measured by DXA may not adequately estimate fracture risk (Mazziotti et al. 2015). Several quantitative computed tomography studies in acromegaly patients found poorer trabecular bone parameters, such as higher trabecular separation and decreased trabecular number and bone volume to tissue volume, in comparison to healthy controls (Maffezzoni 
b)

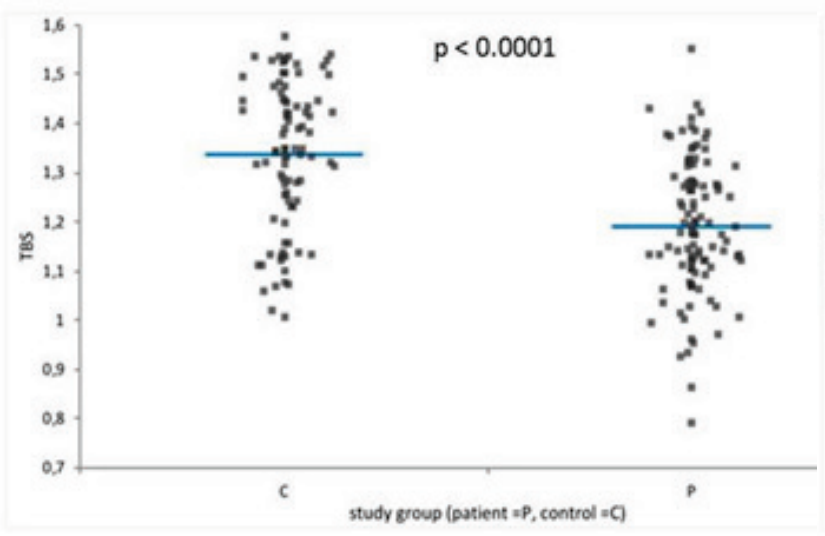

d)

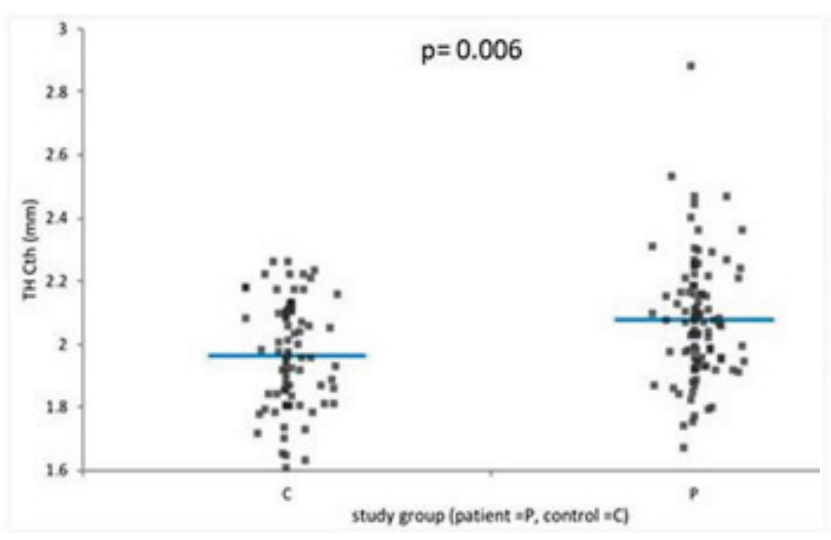

a)

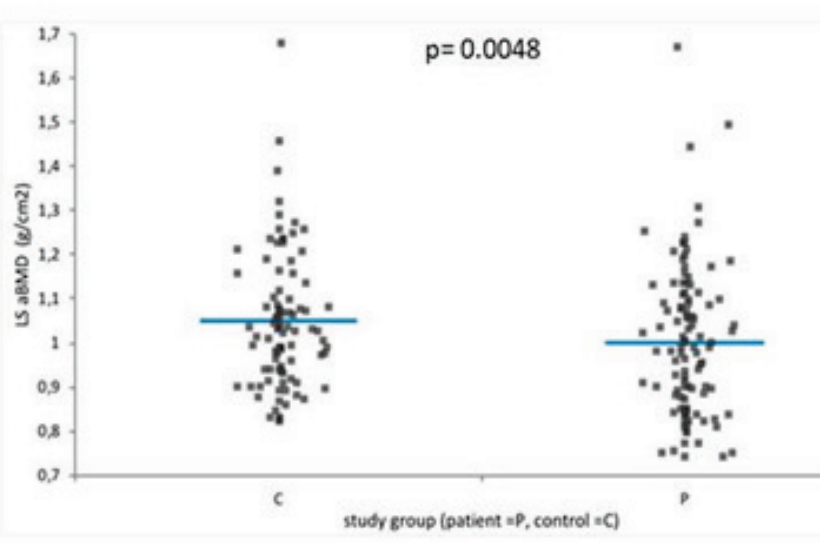

c)

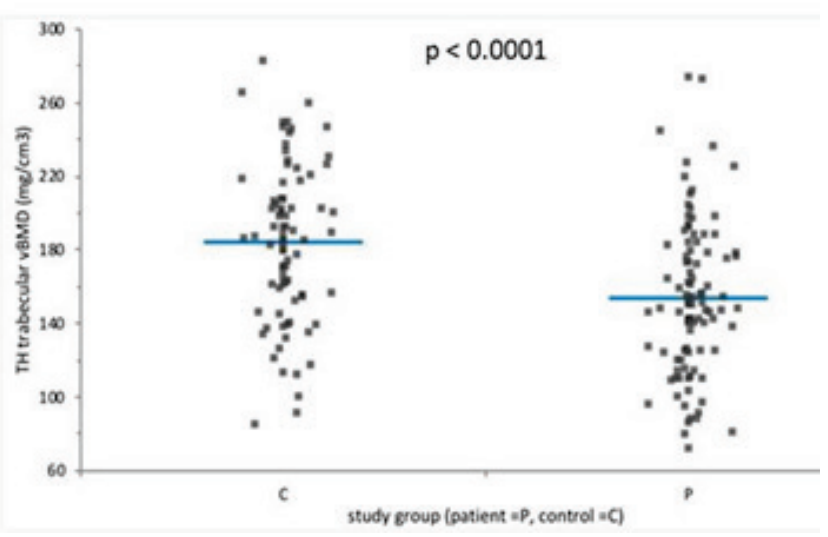

Fig. 5. Comparison of $L S$ aBMD, TBS, TH trabecular VBMD and TH Cth in patients with acromegaly and healthy controls. A lower LS aBMD, TBS and trabecular VBMD at TH and higher Cth was observed in patients with acromegaly in comparison to healthy controls.

et al. 2016). These conclusions are supported by studies with bone microidentation (Malgo et al. 2017) and TBS (Godang et al. 2016, Hong et al. 2016). Finally, bone histomorphometry in acromegaly patients with VFs, showed impaired trabecular parameters (decreased trabecular thickness and increased trabecular separation), in comparison to healthy sex and age-matched adults and also increased cortical thickness and porosity among acromegaly subjects (Carbonare et al. 2018).

In our recent cross-sectional study, DXA-derived bone parameters areal BMD (aBMD), trabecular bone score (TBS) and 3D-SHAPER in patients with acromegaly were compared (Kuzma et al. 2019). 106 patients with acromegaly (mean age 56.6 years, BMI $30.2 \mathrm{~kg} / \mathrm{m}^{2}$ ) and 104 control subjects (mean age 54.06 years, BMI $28.4 \mathrm{~kg} / \mathrm{m}^{2}$ ) were included. Acromegaly patients were heavier, had higher IGF-1 and P1NP levels but lower LH, $\mathrm{FSH}, \mathrm{TSH}, \mathrm{ACTH}$ levels (all $\mathrm{p}<0.05$ ). Considering areal DXA bone parameters, acromegaly patients had significantly lower $(\mathrm{p}<0.05)$ lumbar spine aBMD and TBS when compared to controls while no differences were observed for aBMD at the femoral neck and total hip. Using the 3D modelling approach, acromegaly patients had thicker cortical thickness (Cth) at both the femoral neck $(\mathrm{p}<0.05)$ and $\mathrm{TH} \quad(\mathrm{p} \leq 0.001)$, but significantly lower Trabecular vBMD at both sites [neck $(\mathrm{p}<0.05)$ and $\mathrm{TH}$ $(\mathrm{p}<0.001)]$. After adjustment for weight, LS aBMD, TBS and TH Trabecular vBMD remained significantly lower $(\mathrm{p}=0.0048,<0.0001$ and $<0.0001$ respectively $)$ in acromegaly patients compared with controls. In contrast, Cth (at $\mathrm{TH}$ and Neck) remained significantly thicker $(\mathrm{p}=0.006)$ in acromegaly patients than in controls (Fig. 5).

Considering bone parameters only (2D and 3D), the best multivariate model (Model 1) discriminating patients with and without acromegaly included TBS, $\mathrm{TH}$ Trabecular vBMD and $\mathrm{TH}$ Cth parameters while aBMD LS and weight were excluded from the model (all $\mathrm{p}>0.1$ ). Model 1 (Fig. 6) was associated with the presence of acromegaly as reported by an OR per SD decrease of 4.85 [3.09-7.62] and an AUC of 0.845 [0.787-0.903]. 
AUC of model 1 was significantly greater than AUCs of each of the three co-factors included in this model (all $\mathrm{p}<0.01$ ). This study shows that acromegaly patients after multivariate analysis have lower TBS, trabecular vBMD and higher $\mathrm{Cth}$, as measured by a novel method
3D-Shaper, in comparison to healthy controls. TBS showed the best sensitivity to distinguish between acromegaly and non-acromegaly subjects, proving suitability of TBS as the surrogate of bone microarchitecture in this form of secondary osteoporosis.

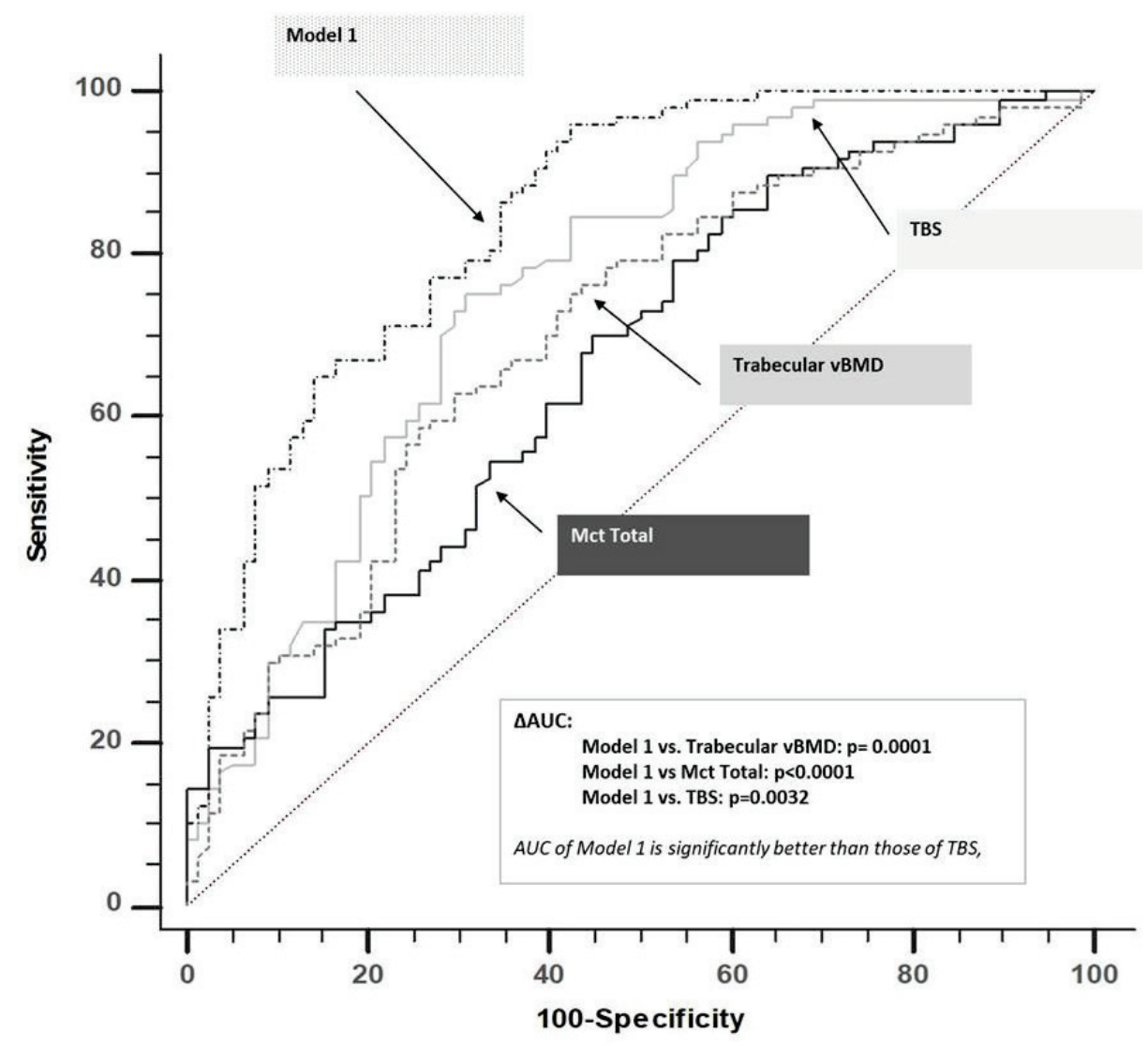

Fig. 6. Considering bone parameters only (2D and 3D), the best multivariate model (Model 1) discriminating patients with and without acromegaly included TBS, TH Trabecular vBMD and TH Cth. However, all three parameters together (Model 1) showed the highest sensitivity and specificity.

\section{Conclusion}

Treatment of GHD with GH increases BMD at all sites over time. RhGH has a biphasic effect on bone; represented by initial phase associated with an increase in bone resorption and a decrease in BMD and a second phase characterized by an increase in bone formation and in BMD, usually after 6-12 months of treatment. In our studies, positive effect on BMD and bone microstructure, as assessed by TBS, was observed. Another study shows that positive GH effect on TBS is maintained only when sufficient vitamin D levels are reached. Acromegaly is associated with increased bone remodeling, and significantly higher prevalence of vertebral fractures. Our study shows possibility to use TBS to distinguish acromegaly patients who are at risk of vertebral fractures. According to results of these studies, TBS seems as the suitable surrogate of bone microstructure and thus fracture risk in patients with GH secretion disorders.

\section{Conflict of Interest}

There is no conflict of interest.

\section{References}

AMATO G, CARELlA C, FAZIO S, LA MG, CITTADINI A, SABATINI D, MARCIANO-MONE C, SACCA L, BELLASTELLA A: Body composition, bone metabolism, and heart structure and function in growth hormone (GH)-deficient adults before and after GH replacement therapy at low doses. J Clin Endocrinol Metab 77: 1671-1676, 1993. 
AMERI P, GIUSTI A, BOSCHETTI M, BOVIO M, TETI C, LEONCINI G, FERONE D, MURIALDO G, MINUTO F: Vitamin D increases circulating IGF1 in adults: potential implication for the treatment of GH deficiency. Eur J Endocrinol 169: 767-772, 2013.

APPELMAN-DIJKSTRA NM, CLAESSEN KM, HAMDY NA, PEREIRA AM, BIERMASZ NR: Effects of up to 15 years of recombinant human $\mathrm{GH}(\mathrm{rhGH})$ replacement on bone metabolism in adults with growth hormone deficiency (GHD): the Leiden Cohort Study. Clin Endocrinol (Oxf) 81: 727-735, 2014.

ARWERT LI, DEIJEN JB, MULLER M, DRENT ML: Long-term growth hormone treatment preserves GH-induced memory and mood improvements: a 10-year follow-up study in GH-deficient adult men. Horm Behav 47: 343-349, 2005.

BARAKE M, KLIBANSKI A, TRITOS NA: Effects of recombinant human growth hormone therapy on bone mineral density in adults with growth hormone deficiency: a meta-analysis. J Clin Endocrinol Metab 99: 852-860, 2014.

BEREKET A, CESUR Y, OZKAN B, ADAL E, TURAN S, ONAN SH, DONERAY H, AKCAY T, HAKLAR G: Circulating insulin-like growth factor binding protein-4 (IGFBP-4) is not regulated by parathyroid hormone and vitamin D in vivo: evidence from children with rickets. J Clin Res Pediatr Endocrinol 2: 17-20, 2010.

BIERMASZ NR, HAMDY NA, JANSSEN YJ, ROELFSEMA F: Additional beneficial effects of alendronate in growth hormone (GH)-deficient adults with osteoporosis receiving long-term recombinant human GH replacement therapy: a randomized controlled trial. J Clin Endocrinol Metab 86: 3079-3085, 2001.

BOGAZZI F, ROSSI G, LOMBARDI M, TOMISTI L, SARDELLA C, MANETTI L, CURZIO O, MARCOCCI C, GRASSO L, GASPERI M, MARTINO E: Vitamin D status may contribute to serum insulin-like growth factor I concentrations in healthy subjects. $J$ Endocrinol Invest 34: e200-203, 2011.

BONADONNA S, MAZZIOTTI G, NUZZO M, BIANCHI A, FUSCO A, DE MARINIS L, GIUSTINA A: Increased prevalence of radiological spinal deformities in active acromegaly: a cross-sectional study in postmenopausal women. J Bone Miner Res 20: 1837-1844, 2005.

BOUTROY S, HANS D, SORNAY-RENDU E, VILAYPHIOU N, WINZENRIETH R, CHAPURLAT R: Trabecular bone score improves fracture risk prediction in non-osteoporotic women: the OFELY study. Osteoporos Int 24: 77-85, 2013.

BRIOT K, PATERNOTTE S, KOLTA S, EASTELL R, REID DM, FELSENBERG D, GLUER CC, ROUX C: Added value of trabecular bone score to bone mineral density for prediction of osteoporotic fractures in postmenopausal women: the OPUS study. Bone 57: 232-236, 2013.

CARBONARE LD, MICHELETTI V, COSARO E, VALENTI MT, MOTTES M, FRANCIA G, DAVI MV: Bone histomorphometry in acromegaly patients with fragility vertebral fractures. Pituitary 21: 56-64, 2018.

CLAESSEN KM, KROON HM, PEREIRA AM, APPELMAN-DIJKSTRA NM, VERSTEGEN MJ, KLOPPENBURG M, HAMDY NA, BIERMASZ NR: Progression of vertebral fractures despite long-term biochemical control of acromegaly: a prospective follow-up study. J Clin Endocrinol Metab 98: 4808-4815, 2013.

CLANGET C, SECK T, HINKE V, WUSTER C, ZIEGLER R, PFEILSCHIFTER J: Effects of 6 years of growth hormone $(\mathrm{GH})$ treatment on bone mineral density in GH-deficient adults. Clin Endocrinol (Oxf) 55: 93-99, 2001.

CONWAY GS, SZARRAS-CZAPNIK M, RACZ K, KELLER A, CHANSON P, TAUBER M, ZACHARIN M: Treatment for 24 months with recombinant human GH has a beneficial effect on bone mineral density in young adults with childhood-onset GH deficiency. Eur J Endocrinol 160: 899-907, 2009.

DAVIDSON P, MILNE R, CHASE D, COOPER C: Growth hormone replacement in adults and bone mineral density: a systematic review and meta-analysis. Clin Endocrinol (Oxf) 60: 92-98, 2004.

DEGERBLAD M, BENGTSSON BA, BRAMNERT M, JOHNELL O, MANHEM P, ROSEN T, THOREN M: Reduced bone mineral density in adults with growth hormone $(\mathrm{GH})$ deficiency: increased bone turnover during 12 months of GH substitution therapy. Eur J Endocrinol 133: 180-188, 1995.

ELBORNSSON M, GOTHERSTROM G, BOSAEUS I, BENGTSSON BA, JOHANNSSON G, SVENSSON J: Fifteen years of GH replacement increases bone mineral density in hypopituitary patients with adult-onset GH deficiency. Eur J Endocrinol 166: 787-795, 2012a. 
ELBORNSSON M, GOTHERSTROM G, FRANCO C, BENGTSSON BA, JOHANNSSON G, SVENSSON J: Effects of 3-year GH replacement therapy on bone mineral density in younger and elderly adults with adult-onset GH deficiency. Eur J Endocrinol 166: 181-189, 2012 b.

GODANG K, OLARESCU NC, BOLLERSLEV J, HECK A: Treatment of acromegaly increases BMD but reduces trabecular bone score: a longitudinal study. Eur J Endocrinol 175: 155-164, 2016.

GOMEZ JM, MARAVALL FJ, GOMEZ N, NAVARRO MA, CASAMITJANA R, SOLER J: Relationship between 25-(OH) D3, the IGF-I system, leptin, anthropometric and body composition variables in a healthy, randomly selected population. Horm Metab Res 36: 48-53, 2004.

HALUPCZOK-ZYLA J, JAWIARCZYK-PRZYBYLOWSKA A, BOLANOWSKI M: Patients with active acromegaly are at high risk of 25(OH)D deficiency. Front Endocrinol (Lausanne) 6: 89, 2015.

HANS D, GOERTZEN AL, KRIEG MA, LESLIE WD: Bone microarchitecture assessed by TBS predicts osteoporotic fractures independent of bone density: the Manitoba study. J Bone Miner Res 26: 2762-2769, 2011.

HONG AR, KIM JH, KIM SW, KIM SY, SHIN CS: Trabecular bone score as a skeletal fragility index in acromegaly patients. Osteoporos Int 27: 1123-1129, 2016.

JORGENSEN AP, FOUGNER KJ, UELAND T, GUDMUNDSEN O, BURMAN P, SCHREINER T, BOLLERSLEV $\mathrm{J}$ : Favorable long-term effects of growth hormone replacement therapy on quality of life, bone metabolism, body composition and lipid levels in patients with adult-onset growth hormone deficiency. Growth Horm IGF Res 21: 69-75, 2011.

JOSEPH F, AHMAD AM, UL-HAQ M, DURHAM BH, WHITTINGHAM P, FRASER WD, VORA JP: Effects of growth hormone administration on bone mineral metabolism, PTH sensitivity and PTH secretory rhythm in postmenopausal women with established osteoporosis. J Bone Miner Res 23: 721-729, 2008.

KAYATH MJ, VIEIRA JG: Osteopenia occurs in a minority of patients with acromegaly and is predominant in the spine. Osteoporos Int 7: 226-230, 1997.

KRANTZ E, TRIMPOU P, LANDIN-WILHELMSEN K: Effect of growth hormone treatment on fractures and quality of life in postmenopausal osteoporosis: A 10-year follow-up study. J Clin Endocrinol Metab 100: 3251-3259, 2015.

KUZMA M, BINKLEY N, BEDNAROVA A, KILLINGER Z, VANUGA P, PAYER J: Trabecular bone score change differs with regard to 25(oh)d levels in patients treated for adult-onset growth hormone deficiency. Endocr Pract 22: 951-958, 2016.

KUZMA M, KUZMOVA Z, ZELINKOVA Z, KILLINGER Z, VANUGA P, LAZUROVA I, TOMKOVA S, PAYER $\mathrm{J}$ : Impact of the growth hormone replacement on bone status in growth hormone deficient adults. Growth Horm IGF Res 24: 22-28, 2014.

KUZMA M, VANUGA P, SAGOVA I, PAVAI D, JACKULIAK P, KILLINGER Z, BINKLEY NC, WINZENRIETH R, GENANT HK, PAYER J: Non-invasive DXA-derived bone structure assessment of acromegaly patients: a cross-sectional study. Eur J Endocrinol 180: 201-211, 2019.

MAFFEZZONI F, MADDALO M, FRARA S, MEZZONE M, ZORZA I, BARUFFALDI F, DOGLIETTO F, MAZZIOTTI G, MAROLDI R, GIUSTINA A: High-resolution-cone beam tomography analysis of bone microarchitecture in patients with acromegaly and radiological vertebral fractures. Endocrine 54: 532-542, 2016.

MALGO F, HAMDY NAT, PAPAPOULOS SE, APPELMAN-DIJKSTRA NM: Bone material strength index as measured by impact microindentation is low in patients with fractures irrespective of fracture site. Osteoporos Int 28: 2433-2437, 2017.

MAZZIOTTI G, BIAGIOLI E, MAFFEZZONI F, SPINELLO M, SERRA V, MAROLDI R, FLORIANI I, GIUSTINA A: Bone turnover, bone mineral density, and fracture risk in acromegaly: a meta-analysis. $J$ Clin Endocrinol Metab 100: 384-394, 2015.

MAZZIOTTI G, BIANCHI A, PORCELLI T, MORMANDO M, MAFFEZZONI F, CRISTIANO A, GIAMPIETRO A, DE MARINIS L, GIUSTINA A: Vertebral fractures in patients with acromegaly: a 3-year prospective study. J Clin Endocrinol Metab 98: 3402-3410, 2013. 
MCCLOSKEY EV, ODEN A, HARVEY NC, LESLIE WD, HANS D, JOHANSSON H, BARKMANN R, BOUTROY S, BROWN J, CHAPURLAT R, ELDERS PJM, FUJITA Y, GLUER CC, GOLTZMAN D, IKI M, KARLSSON M, KINDMARK A, KOTOWICZ M, KURUMATANI N, KWOK T, LAMY O, LEUNG J, LIPPUNER K, LJUNGGREN O, LORENTZON M, MELLSTROM D, MERLIJN T, OEI L, OHLSSON C, PASCO JA, RIVADENEIRA F, ROSENGREN B, SORNAY-RENDU E, SZULC P, TAMAKI J, KANIS JA: A meta-analysis of trabecular bone score in fracture risk prediction and its relationship to FRAX. J Bone Miner Res 31: 940-948, 2016.

MIRZA F, CANALIS E: Management of endocrine disease: Secondary osteoporosis: pathophysiology and management. Eur J Endocrinol 173: R131-151, 2015.

MO D, FLESERIU M, QI R, JIA N, CHILD CJ, BOUILLON R, HARDIN DS: Fracture risk in adult patients treated with growth hormone replacement therapy for growth hormone deficiency: a prospective observational cohort study. Lancet Diabetes Endocrinol 3: 331-338, 2015.

RIGGS BL, RANDALL RV, WAHNER HW, JOWSEY J, KELLY PJ, SINGH M: The nature of the metabolic bone disorder in acromegaly. J Clin Endocrinol Metab 34: 911-918, 1972.

ROSEN T, WIREN L, WILHELMSEN L, WIKLUND I, BENGTSSON BA: Decreased psychological well-being in adult patients with growth hormone deficiency. Clin Endocrinol (Oxf) 40: 111-116, 1994.

ROTA F, SAVANELLI MC, TAUCHMANOVA L, SAVASTANO S, LOMBARDI G, COLAO A, DI SC: Bone density and turnover in young adult patients with growth hormone deficiency after 2-year growth hormone replacement according with gender. J Endocrinol Invest 31: 94-102, 2008.

SCILLITANI A, CHIODINI I, CARNEVALE V, GIANNATEMPO GM, FRUSCIANTE V, VILLELLA M, PILERI M, GUGlielmi G, DI GIORGIO A, MODONI S, FUSILli S, DI CERBO A, LIUZZI A: Skeletal involvement in female acromegalic subjects: the effects of growth hormone excess in amenorrheal and menstruating patients. J Bone Miner Res 12: 1729-1736, 1997.

SOLIMAN AT, AL KHALAF F, ALHEMAIDI N, AL ALI M, AL ZYOUD M, YAKOOT K: Linear growth in relation to the circulating concentrations of insulin-like growth factor I, parathyroid hormone, and 25-hydroxy vitamin $\mathrm{D}$ in children with nutritional rickets before and after treatment: endocrine adaptation to vitamin D deficiency. Metabolism 57: 95-102, 2008.

STEPAN J, MAREK J, HAVRANEK T, DOLEZAL V, PACOVSKY V: Bone isoenzyme of serum alkaline phosphatase in acromegaly. Clin Chim Acta 93: 355-363, 1979.

TOUSKOVA V, KLOUCKOVA J, DUROVCOVA V, LACINOVA Z, KAVALKOVA P, TRACHTA P, KOSAK M, MRAZ M, HALUZIKOVA D, HANA V, MAREK J, KRSEK M, HALUZIK M: The possible role of mRNA expression changes of GH/IGF-1/insulin axis components in subcutaneous adipose tissue in metabolic disturbances of patients with acromegaly. Physiol Res 65: 493-503, 2016.

UELAND T, BOLLERSLEV J, GODANG K, MULlER F, FROLAND SS, AUKRUST P: Increased serum osteoprotegerin in disorders characterized by persistent immune activation or glucocorticoid excess--possible role in bone homeostasis. Eur J Endocrinol 145: 685-690, 2001.

VESTERGAARD P, MOSEKILDE L: Fracture risk is decreased in acromegaly - a potential beneficial effect of growth hormone. Osteoporos Int 15: 155-159, 2004. 